\title{
Rivista di estetica
}

$70 \mid 2019$

Philosophy and Literature

\section{Like giants immersed in time. Ontology, phenomenology, and Marcel Proust}

\section{Maurizio Ferraris and Enrico Terrone}

\section{(2) OpenEdition \\ Journals}

\section{Electronic version}

URL: http://journals.openedition.org/estetica/5146

DOI: 10.4000/estetica.5146

ISSN: 2421-5864

\section{Publisher}

Rosenberg \& Sellier

\section{Printed version}

Date of publication: 1 April 2019

Number of pages: 92-106

ISSN: 0035-6212

\section{Electronic reference}

Maurizio Ferraris and Enrico Terrone, «Like giants immersed in time. Ontology, phenomenology, and Marcel Proust », Rivista di estetica [Online], 70 | 2019, Online since 01 February 2020, connection on 27 February 2020. URL : http://journals.openedition.org/estetica/5146 ; DOI : 10.4000/estetica. 5146

\section{(c)}

Rivista di Estetica è distribuita con Licenza Creative Commons Attribuzione - Non commerciale - Non opere derivate 4.0 Internazionale. 


\section{Maurizio Ferraris, Enrico Terrone \\ LIKE GIANTS IMMERSED IN TIME. ONTOLOGY, PHENOMENOLOGY, AND MARCEL PROUST*1}

\section{Abstract}

Marcel Proust's In Search of Lost Time, raises an interesting philosophical issue, namely, how can one be in touch with past things if they no longer exist? It provides us with a way to address this issue by outlining an ontological view according to which past things still exist within a four-dimensional world. Although one cannot be in touch with past things by means of ordinary perception, one can do so by combining perception and memory. In this sense, In Search of Lost Time helps us to reconcile a four-dimensionalist ontology according to which things have both spatial and temporal parts with a realist phenomenology according to which experience gives us access to things as they are. In so doing, Proust's masterpiece allows us to shed some light on what it means for a subject of experience to exist in a four-dimensional world.

\section{It no longer exists but I can perceive it}

Many years have passed since that night. The wall of the staircase up which I had watched the light of his candle gradually climb was long ago demolished [n'existe plus depuis longtemps]. And in myself, too, many things have perished which I imagined would last for ever, and new ones have arisen, giving birth to new sorrows and new joys which in those days I could not have foreseen, just as now the old are hard to understand. It is a long time, too, since my father has been able to say to Mamma:

\footnotetext{
${ }^{1}$ Both authors made equal contributions to the project of this paper. Maurizio Ferraris directly wrote sections 2 and 5, Enrico Terrone sections 1, 3 and 4. The paper was presented at "Metaphysical Questions: An International Conference" (Università degli Studi di Milano, Palazzo Feltrinelli, Gargnano sul Garda, Brescia, 29 October 2015) and at "Philosophical Symposium: Composition as Diversity - Experiencing Ontological Wholes" (Scuola di Dottorato in Scienze Umanistiche e della Società, Università di Ferrara, 3 June 2015). The authors want to thank the organizers and the audiences of these events.
}

Rivista di estetica, n.s., n. 70 (1/2019), LIX, pp. 92-106 C Rosenberg \& Sellier 
"Go along with the child". Never again will such moments be possible for me. But of late I have been increasingly able to catch, if I listen attentively, the sound of the sobs which I had the strength to control in my father's presence, and which broke out only when I found myself alone with Mamma. In reality their echo has never ceased; and it is only because life is now growing more and more quiet round about me that $I$ hear them anew, like those convent bells which are so effectively drowned during the day by the noises of the street that one would suppose them to have stopped, until they ring out again through the silent evening $\operatorname{air}^{2}$.

As evidenced by the phrases we have italicized, this passage from Swann's Way contains two opposing elements. On the one hand, Proust tells us that the world of his childhood no longer exists, on the other he claims to be able to perceive it. Given that perception is a factive mental state, which implies the existence of its objects, perceiving "the sound of the sobs which I had the strength to control in my father's presence, and which broke out only when I found myself alone with Mamma" signifies the existence of those sobs. This seems to contradict the previous statement that "The wall of the staircase up which I had watched the light of his candle gradually climb was long ago demolished" - unless a child's sobs have a more robust ontological status than a stairway, which seems implausible.

The philosophical significance of this literary contradiction has been analyzed by Emanuele Lago $^{3}$ in his essay La volontà di potenza e il passato [The Will to Power and the Past], in the chapter entitled "Proust, Nietzsche, Gentile, and the impossibility of the will to power". First of all, Lago highlights Proust's contradiction: "By arguing that the past continues to be perceived, does not Proust (like the Western speculative tradition to which he refers) fall into the most obvious contradiction? Is he not saying that the thing ceases and yet does not cease to exist, that it is annulled (because it passes) and yet is not annulled (because it continues to be perceived)?" ${ }^{4}$. Secondly, Lago focuses on the strategy that Proust uses to solve this contradiction. This strategy consists in giving memory the task of making the perception of the past possible by guaranteeing its being. This presupposes an "idealist" conception of the relationship between memory and the past, by which the being of the latter depends on the thinking subject and her memory: "This conception of memory as unconscious survival of the past is the way in which Proust, in the wake of Bergson, expresses the fundamental meaning of memory in the Western tradition. It is essentially a way to preserve what exists and keep it in the sphere of being, saving it from the robbery

\footnotetext{
${ }^{2}$ Proust 1913-1927: 49-50.

${ }^{3}$ Lago 2005.

${ }^{4}$ Ibidem: 261.
} 
of nothingness"s. In this way, the past "remains in the depths of the soul (those depths that are for the artist to probe)" 6 .

However, according to Lago, Proust's solution is contradictory: on the one hand, the past preserved by memory is subtracted from the flow of becoming; on the other hand, the past, as being in time, has the essential characteristic of becoming - of passing from being to nothing - otherwise there would be no need for memory to preserve it. That is to say, the past has the essential characteristic of becoming, but memory preserves the past without this essential characteristic; therefore memory does not really preserve the past.

Lago's conclusion is that in order to solve this problem it is necessary to dismiss Proust and turn instead to Gentile and Nietzsche, two philosophers well aware that "the evidence of becoming is necessarily connected with the idea that nothing may exist outside of its relationship with it" . From this principle, however, Gentile and Nietzsche draw opposite consequences.

Gentile claims that the past is unreal, and therefore it is impossible to experience it through memory, which instead "creates it from scratch". Thus, the moderate idealism that Lago attributes to Proust (for which memory preserves the past) gives way to Gentile's radical idealism (for which memory creates the past). Nietzsche's solution instead consists in affirming that the past continues to become independently of memory; what makes this possible is the eternal return, such that: «Every moment (every configuration of the world) is the identical recreation of the most remote past» ${ }^{9}$. This solution can be seen as a kind of prodigal realism, in the sense that it affirms the reality of the past (which is why it is a form of realism), but it does so by multiplying events at will (which is why it is prodigal).

In what follows, we will argue that there is another strategy to solve the Proustian contradiction between the alleged nonexistence of the past and the fact that it can be experienced. This strategy does not require resorting to either Gentile or Nietzsche; it does not oblige us to endorse either the radical idealism of the former or the prodigal realism of the latter. Proust's contradiction can in fact be addressed and resolved within Proust's very text. To this end, however, we need to move from the beginning of In Search of Lost Time to its final volume, Time Regained, where the Proustian conception of the past clearly turns out to be realistic rather than idealistic. In fact, for Proust, the past continues to exist independently of memory, which simply experiences it in a manner

\footnotetext{
${ }^{5}$ Ibidem: 264.

${ }^{6}$ Ibidem: 267.

${ }^{7}$ Ibidem: 268.

${ }^{8}$ Ibidem: 270.

${ }^{9}$ Ibidem: 283.
} 
similar to that in which perception experiences the present. This form of realism about the past is quite distinct from the Nietzschean eternal return, for which the past continues to exist, repeating itself endlessly. In Proust's perspective, one occurrence alone is sufficient for a past event to exist eternally. This is the conception of time that, in contemporary philosophy, goes under the name of four-dimensionalism.

\section{Ontology}

In Search of Lost Time has been the object of various philosophical readings, both on the "analytic" side ${ }^{10}$ and on the "continental" side ${ }^{11}$. Here, we intend to read it as a philosophical Bildungsroman in which one learns a new way of looking at things, a new modality to experience time. From this point of view, the passage from lost time to time regained is not a change in the nature of time itself, but in the way we experience it. Time remains there, where it has always been. It was lost because one was no longer able to see it; it is regained when one finds a way to see it again: "like those convent bells which are so effectively drowned during the day by the noises of the street that one would suppose them to have stopped, until they ring out again through the silent evening air". The bells do not actually resume playing; they never stopped, yet one did not know how to listen to them. Similarly, the past does not return to reality; it has always been real, yet one was no longer able to see it. When one learns to see it again, time is regained.

This reading of In Search of Lost Time can be clarified by using the theoretical tools made available by the debate on time and the experience of time in contemporary philosophy. In accordance with the image of the world derived from Einstein's theory of relativity, philosophers such as Quine ${ }^{12}$, Mellor ${ }^{13}$, Varzi $^{14}$ and Sider ${ }^{15}$ conceive of time as a fourth spatial dimension, and therefore only consider the notions of precedence between temporal instants along this dimension. Instead, for them, the characteristics of past, present or future that are usually attributed to the temporal instants in the manifest image of the world are simple subjective appearances. Let us call "Einsteinian image" the image of the world endorsed by these philosophers.

\footnotetext{
${ }^{10}$ For instance, Bonomi 1987.

${ }^{11}$ For instance, Deleuze 1964.

${ }^{12}$ Quine 1987.

${ }^{13}$ Mellor 1998.

${ }^{14}$ Varzi 2001.

${ }^{15}$ Sider 2011.
} 
Borrowing McTaggart's ${ }^{16}$ terminology, the Einsteinian image involves a $B$-theory of time, which attributes reality only to temporal relations of precedence between instants; instead, an A-theory of time also attributes reality to the properties of "being past", "being present" or "being future", which can be attributed to individual instants. Moreover, the einsteinian image is eternalist because the existence of something does not depend on its temporal position; instead, according to the presentist conception, only that which enjoys the property of being present exists. Finally, the einsteinian image is four-dimensionalist, because it conceives of concrete objects as extended not only in space but also in time; instead, according to a three-dimensionalist conception, objects are essentially spatial and therefore three-dimensional: they do not extend in time, but rather change over time. Thus, according to three-dimensionalism, an object can be wholly present at a single point in time whereas, according to four-dimensionalism, the object fills time with its temporal parts just as it fills space with its spatial parts.

The conception of time that emerges from In Search of Lost Time surely is four-dimensionalist, even though it does not explicitly endorse a B-theory of time or eternalism. Consider how the Narrator describes Combray's church: "an edifice occupying, so to speak, a four dimensional space - the name of the fourth being Time"17. Or consider the ending passage in which the Narrator sees the participants in the Guermantes matinee as "giants immersed in time"18, whose appearance is the visible, three-dimensional part of a four-dimensional body that has its roots in the past. This is Proust's four-dimensionalism, which, in the domain of literary studies, has been nicely highlighted by Richard Durán ${ }^{19}$ in his paper Fourth-Dimensional Time and Proust's 'A la recherche du temps perdu'.

In principle, four-dimensionalism does not necessarily imply that the present lacks reality and all moments, past, present and future, exist all together in a single eternal whole. That is to say that four-dimensionalism does not per se imply the B-theory of time and eternalism. There are two main options in this regard. If one supports the A-theory together with eternalism and four-dimensionalism, one is endorsing a moving spotlight theory ${ }^{20}$. According to this view, the universe exists as an eternal four-dimensional block, but inside it there is a privileged moment, the present, which moves along the temporal dimension of the four-dimensional block as if there were a moving spotlight illuminating the various instants one at a time. If instead one maintains the A-theory and

\footnotetext{
${ }^{16}$ McTaggart 1908.

${ }^{17}$ Proust 1913-1927: 66.

${ }^{18}$ Ibidem: 1012.

${ }^{19}$ Durán 1991.

${ }^{20}$ See Cameron 2015.
} 
four-dimensionalism, but not eternalism, one is endorsing a growing block theory $^{21}$, for which the four-dimensional universe is built as the bar of the present moves forward from the past to the future.

The four-dimensional conception of reality, in principle, is compatible with both moving spotlight theory and growing block theory. It is instead incompatible with presentism, the thesis that only what is present exists. In fact, presentism involves not only the adoption of the A-theory (otherwise the notion of present would have no ontological relevance) but also the rejection of four-dimensionalism (because if only the present exists, then - given that the present is point-like - there can be no four-dimensional entities). If one endorses presentism, three-dimensionalism is the only choice, and from that perspective Proust's statement that "the sobs which I had the strength to control in my father's presence» have never ceased reveals itself to be nothing more than a poetic metaphor; the sobs, belonging to the past, have ceased a long time ago, because only the present really exists. If one wants to treat these sobs as truly real, four-dimensionalism is the only available option.

\section{Phenomenology and Epistemology}

A point in favor of three-dimensionalism seems to be its conformity with the phenomenology and epistemology of ordinary experience. If we look around, we see three-dimensional objects, not four-dimensional ones. So, three-dimensionalism can take perceptual experience at face value, while four-dimensionalism seems forced to provide an "error theory"22, that is, an explanation of why we perceive three-dimensional objects if in reality the world is made up of four-dimensional entities.

As we will see, Proust offers us an alternative to this error theory: the point is not to explain why our perception is wrong, but rather to make it truthful, enriching it with the contribution of memory. But before proceeding to analyze the proustian solution, let us try to clarify the scope of the problem. To this end, consider Peter Strawson's criticism of four-dimensionalism in his book Individuals:

So some philosophers have reasoned, making their point by saying, for example, that 'Caesar' is the name of a series of events, a biography. In so reasoning, they may be said to draw attention to the possibility of our recognizing a category of objects which we do not in fact recognize: a category of four-dimensional objects, which might be called 'process-things', and of which each of the temporally successive parts is three-dimensional, is, as it were, the thing taken at successive stages of its history from the beginning to the end. But the way in which I have to describe these objects shows that they are not to

${ }^{21}$ See Broad 1923.

${ }^{22}$ Cf. Mackie 1977. 
be identified either with the processes which things undergo or with the things which undergo them. I remarked earlier that I was concerned to investigate the relations of identifiability-dependence between the available major categories, the categories we actually possess; and the category of process-things is one we neither have nor need ${ }^{23}$.

There is something puzzling in this argument. Why does Strawson presuppose that we lack the category of process-things? This is not very clear. Consider the individual we are referring to when we say, for example, "Socrates was a wise man". What metaphysical category does he belong to? It is not obvious whether we are speaking of a three-dimensional thing (like a body) or of a process-thing (like a biography, a whole life).

In fact, Strawson's point seems to be that one cannot perceive process-things. One only perceives three-dimensional objects. Therefore, one can only identify and recognize (and speak of) three-dimensional objects, not process-things.

Still, one does not need to perceive an object in its entirety in order to identify it. One can identify an object by simply perceiving a spatial part of it. As Alva Noë ${ }^{24}$ pointed out, one experiences a tomato as a voluminous ovoid even though one only sees one side of it. Perception rests upon "synecdoches", i.e. parts standing for a whole. We can draw on this to establish an experiential analogy between the experience of space and that of time. As a two-dimensional facet can stand for a three-dimensional spatial whole, so a three-dimensional "facet" can stand for a four-dimensional spatiotemporal whole. In this sense, the temporal dimension of a four-dimensional entity is a sort of hidden depth. This leads us to a significant experiential analogy between space and time: just as one has access to objective space (which can be represented by a map) by experiencing egocentric perspectival space (centered in the place where our body is), one also has access to objective time (which can be represented by a calendar) by experiencing egocentric perspectival time (centered in the time at which our perception occurs).

However, there is also a significant experiential disanalogy between space and time. As Merleau Ponty ${ }^{25}$ observed, "I know that objects have several facets because I could make a tour of inspection of them", and yet one cannot make a tour of inspection of a four-dimensional entity.

Nevertheless, one can experience further temporal facets of such a four-dimensional entity by means of memory. Surely, in terms of pure perception, one can only have temporal experience of three-dimensional objects. Yet temporal experience is rarely, if ever, pure perception: it is rather a combination of perception and memory. This becomes evident in memory-based (or retention-based)

\footnotetext{
${ }^{23}$ Strawson 1959: 56-57.

${ }^{24}$ Noë 2006.

${ }^{25}$ Merleau-Ponty 1945; engl. tr. 1962: 94.
} 
accounts of temporal experience offered by philosophers such as Augustine, Kant, Brentano, Husserl, James, or Bergson.

An interesting example in this sense the experience of a musical interval, say, $\mathrm{C}$-E. This experience results from the conjunction of the very recent memory of $\mathrm{C}$ with the current perception of $\mathrm{E}$. In Brentano's terms, this experience has two components, namely, aesthesis, which represents-as-present $\mathrm{E}$, and proter-aesthesis, which represents-as-recent-past $\mathrm{C}^{26}$.

Musical intervals, qua sounds, are paradigmatic process-things. One does not experience sounds as wholly present entities that can last over time or change, but rather as entities made up of temporal parts. As David Velleman ${ }^{27}$ put it, a sound "doesn't move with respect to time; it merely extends newer and newer temporal parts to fill each successive moment". Four-dimensionalism can be seen as the ontological claim that all things exist in the way sounds exist. In other words, all things are process-things, which, as Proust puts it "are larger than the moment in which they occur and cannot be entirely contained in it" 28 .

The experience of process-things relies on the experiential component in between perception and memory, which Brentano - as seen above - calls "proter-aesthesis", and Husserl "adumbration". Interestingly, Husserl uses this term to indicate not only the retention of a previous temporal state, but also the perception of a spatial facet of a concrete object. As regards adumbrations in the temporal dimension, he observes: "The past must be represented in this now as past, and this is accomplished through the continuity of adumbrations that in one direction terminates in the sensation-point and in the other direction becomes blurred and indeterminate" 29 . In a similar vein, James introduces the notion of a "specious present", which he characterizes in the following terms: "We seem to feel the interval of time as a whole, with its two ends embedded in it"30.

Drawing on these insights on temporal experience, we can conceive of memory as a way of extending "the interval of time as a whole". That is to say that memory is as a way of looking beyond the point that "becomes blurred and indeterminate" in perception and retention. This brings us to the epistemological view called direct realism, according to which remembering involves a direct relation to what exists in the past ${ }^{31}$, just as perceiving involves a direct relation

\footnotetext{
${ }^{26}$ Cf. Kriegel 2015.

${ }^{27}$ Velleman 2006: 13.

${ }^{28}$ Proust 1913-1927: 408.

${ }^{29}$ Husserl 1928; engl. tr. 1991: 290.

${ }^{30}$ James 1890: 574.

${ }^{31}$ Cf. Bergson 1896; Russell 1913.
} 
to what exists in the present ${ }^{32}$. A direct relation, unlike a representation, entails the existence of both its relata, namely, the mental state of perceiving or remembering on the one hand, and what is perceived or remembered on the other.

According to canonical direct realism about perception, by perceiving we enjoy a direct relation to three-dimensional objects. But what parts of reality are we related to by remembering? A reasonable answer seems to be: facets of four-dimensional objects. If this is right, also direct realism about perception might ultimately concern facets of four-dimensional objects. This conclusion is rather sympathetic with Bergson's view, for which three-dimensional objects are nothing but abstractions isolated from a (four-dimensional) whole by abstract thought.

In Time Regained, Proust explicitly connects direct realism about memory to a four-dimensional ontology. He suggests an account according to which "the mental effort of combining eye and memory" allows us to experience objects for what they really are, that is, "monsters occupying a place in Time infinitely more important than the restricted one reserved for them in space, a place, on the contrary, prolonged immeasurably since simultaneously touching widely separated years and the distant periods they have lived through - between which so many days have ranged themselves - they stand like giants immersed in Time" 33 .

Here, Proust reveals himself to be an ontological realist about the past (that is, a four-dimensionalist), and an epistemological realist about memory (that is, a direct realist). He believes that the past exists independently of experience and thought (ontological realism), but also thinks that memory, as such, puts us in touch with the reality of the past (epistemological realism). In contemporary philosophy, epistemological realism - or direct realism - is primarily adopted in philosophy of perception ${ }^{34}$. However, if we consider perception and memory as components of a unitary system of experience, then we have good reasons to follow Proust and extend epistemological realism also to memory, thereby making the temporal experience compliant with a four-dimensionalist ontology.

\section{The atemporal self}

From a four-dimensionalist perspective, all things are process-things. However, to argue that a chair is a four-dimensional entity of which we only perceive a three-dimensional facet is one thing, but to claim the same about ourselves is quite different. In particular, conceiving of the self as a process-thing leads to the following issues: if me-at-t1 (in the past) and me-at- $\mathrm{t} 2$ (in the present) are

\footnotetext{
${ }^{32}$ Cf. Strawson 1979; Snowdon 1998.

${ }^{33}$ Proust 1913-1927: 1012.

${ }^{34}$ See Martin 2002.
} 
both facets of a four-dimensional self, then why, at $\mathrm{t} 2$, can I only be aware of my experience at $\mathrm{t} 2$ and not also of my experience at $\mathrm{t} 1$ ? In what sense does my experience at $\mathrm{t} 1$ still exist as a facet of my four-dimensional self? Can there be such a thing as an experience of mine which exists without being currently enjoyed by me?

One way to address these questions consists in stating that, at $\mathrm{t} 2$, I cannot enjoy my experience at $\mathrm{t} 1$ because myself-at- $\mathrm{t} 2$ can only enjoy my experience at $\mathrm{t} 2$. That is to say that, at $\mathrm{t} 2$, me-at-t 1 is out of my reach just as the hidden face of an object. And yet, this raises a new question: namely, does the experience of me-at-t 1 still exist as an experience? We are going to consider three ways to answer this new question. The first refers to Bergson's philosophy, the second to Berkeley's, and the third to Proust's.

At the ontological level, the first, Bergson-inspired strategy combines four-dimensionalism with the A-theory and the growing-block theory or the moving spotlight theory. In other words, we are in a four-dimensional world in which time actually flows. What results is a growing (or moving) self that has experience only in the present moment (the temporal point where the block grows or the spotlight moves). This seems rather close to the view endorsed by Bergson. From this perspective, we can keep thinking of the self as a four-dimensional entity, but we are forced to ascribe to its present facet (me-at-t2) a feature that its past facets (me-at-t1) currently lack, namely conscious experience. As Brad Skow ${ }^{35}$ puts it, "Of all the experiences I will ever have, some of them are special. Those are the ones that I am having Now. All those others are ghostly and insubstantial".

The second, Berkeley-inspired strategy, instead, combines four-dimensionalism with the B-theory. We are therefore in a four-dimensional world in which the passing of time is only an appearance. What results is a series of "momentary selves" such that "you are only a system of floating ideas, without any substance to support them", as Berkeley wrote in his Three Dialogues between Hylas and Philonous. The unitary enduring self is nothing but an appearance, just as the passage of time. From this perspective, both me-at-t 2 (in the past) and me-at-t 1 (in the present) exist in the same way, namely as (stage-bounded) floating ideas or momentary selves. The unitary self and its sense of presentness are just an illusory effect common to all these floating ideas.

In his paper Self, Mind and Body, Peter Strawson summarized this view - which nevertheless he does not endorse - in the following terms: "Wherever you say there's one continuing soul-substance, I say there's a whole series of them each of which transmits its states and the consciousness of them, to its successor, as motion might be transmitted from one to another of a whole series of elastic

${ }^{35}$ Skow 2009: 677, $\$ 4$. 
balls"36. In his book Selves, Galen Strawson ${ }^{37}$ - Peter's son - endorses and develops such an insight, building up a fully-fledged theory of personal identity according to which the unitary self is nothing but a series of short-living selves. Contemporary philosophers who embrace a similar conception of the self also include Daniel Dennett ${ }^{38}$ and Laurie Paul ${ }^{39}$.

The third, Proust-inspired strategy also combines four-dimensionalism and the B-theory, but without seeing the self as nothing but a system of floating ideas or short-living selves. According to this strategy, the reality of the self is not reduced to a mere series of momentary selves; the self rather exists as a whole made up of momentary selves, which are its temporal parts. This is Proust's theory of an "atemporal self", which lies outside of time and can have several experiences at different times (me-at-t1, me-at-t $2 \ldots$ ) all at once. This Proustian conception of the self has been criticized by Jonathan Dancy in his paper New Truths in Proust? $?^{40}$ and by Gregory Currie in Can There Be a Literary Philosophy of Time ${ }^{21}$ Both Dancy and Currie argue that there is no way to make sense of this notion of an atemporal self. In what follows, we shall defend Proust from Dancy's and Currie's criticism by connecting his notion of an atemporal self to his four-dimensionalist ontology.

The idea is that the momentary self is a facet of the atemporal self, just as, from a four-dimensionalist perspective, a three-dimensional concrete object is a facet of a four-dimensional concrete object. In Velleman's terms, "I would think of myself as filling time rather than passing through it or having it pass me by - as existing in time the way a rooted plant exists in space, growing extensions to occupy it without moving in relation to it. Having shed the illusion of an enduring self, I would have lost any sense of time as passing at all”'42.

From this perspective, "atemporal self" does not means a self absolutely outside time, unlike what Paul Ricoeur ${ }^{43}$ argues in his interpretation of In Search of Lost Time. Rather "atemporal self" means a self outside the passage of time. The atemporal self is outside time only in the sense that it extends in time instead of enduring in time. This is the core of Durán's ${ }^{44}$ criticism of Ricoeur's

\footnotetext{
${ }^{36}$ Strawson 1974: 192.

${ }^{37}$ Strawson 2009.

${ }^{38}$ Dennett 1991.

${ }^{39}$ Paul 2013.

${ }^{40}$ Dancy 1995.

${ }^{41}$ Currie 2004.

${ }^{42}$ Velleman 2006: 14.

${ }^{43}$ Ricoeur 1984.

${ }^{44}$ Durán 1991.
} 
interpretation. Drawing on some insights from Gerard Genette's essay Proust palimpseste ${ }^{45}$, Durán states that

Ricoeur's distinction between the extra-temporal and the recapture of lost time is not only needless, it is invalid. As the text indicates, only the narrator's extra-temporal being - his being outside of the vehicle - can recapture lost time. In effect, the 'extra-temporal,' the 'timeless,' the 'eternal,' 'temps à l'état pur,' the 'recapture of lost time' or 'time regained' are analogous. They all reside outside passing time in synchronic total time (1991: 79).

\section{In Search of Lost Time, or the Children's Crusade}

Even though all momentary "diachronic" selves exist as parts of an atemporal "syncronic" self, some of them can get close to the being of the atemporal self they make up. One can guess what it is like to be such a privileged atemporal self in special experiences like those described by Proust:

And I began to discover the cause by comparing those varying happy impressions which had the common quality of being felt simultaneously at the actual moment and at a distance in time, because of which common quality the noise of the spoon upon the plate, the unevenness of the paving-stones, the taste of the madeleine, imposed the past upon the present and made me hesitate as to which time I was existing in. Of a truth, the being within me which sensed this impression, sensed what it had in common in former days and now, sensed its extra-temporal character, a being which only appeared when through the medium of the identity of present and past, it found itself in the only setting in which it could exist and enjoy the essence of things, that is, outside Time. That explained why my apprehensions on the subject of my death had ceased from the moment when I had unconsciously recognised the taste of the little madeleine because at that moment the being that I then had been was an extra-temporal being and in consequence indifferent to the vicissitudes of the future ${ }^{46}$.

In the passages we have italicized, Proust seems to embrace not only four-dimensionalism but also the B-theory and eternalism. In fact, like the past and the present, the future also falls under the jurisdiction of the atemporal self. In particular, "apprehensions on the subject of my death had ceased" because the atemporal self was already dead, and always had been: its death is nothing but the limit of its time scope, just as its birth.

In this passage of Time Regained, Proust goes on to talk about the relationship between atemporal self and the momentary selves that make it up:

\footnotetext{
${ }^{45}$ Genette 1966.

${ }^{46}$ Proust 1913-1927: 904, our emphasis.
} 
That being had never come to me, had never manifested itself except when I was inactive and in a sphere beyond the enjoyment of the moment, that was my prevailing condition every time that analogical miracle had enabled me to escape from the present. Only that being had the power of enabling me to recapture former days, Time Lost, in the face of which all the efforts of my memory and of my intelligence came to nought ${ }^{47}$.

Here, the atemporal self, "that being", looks like an omniscient alien visitor that can appear to the temporary selves and reveal their very essence to them. This allows us to draw, in conclusion, a comparison between In Search of Lost Time and another masterpiece of twentieth-century literature, namely Kurt Vonnegut's novel Slaughterhouse-Five, or The Children's Crusade.

An extra-temporal being manifests itself to the Narrator of In Search of Lost Time just as the Tralfamadorians, the alien creatures who know the truth about the nature of time, appear to Billy Pilgrim in Slaughterhouse-Five. Like Proust's atemporal self, "The Tralfamadorians can look at the different moments just the way we can look at a stretch of the Rocky Mountains, for instance. They can see how permanent all the moments are, and they can look at any moment that interests them" ${ }^{\prime 8}$. Other significant analogies can be drawn in this respect. For instance, as in Time Regained the Narrator sees Princesse de Guermantes's guests old and worn out, but can also glimpse their lively and sparkling past, so in Slaughterhouse-Five, "When a Tralfamadorian sees a corpse, all he thinks is that the dead person is in bad condition in that particular moment, but that the same person is just fine in plenty of other moments" ${ }^{49}$. And as the Narrator sees Princesse de Guermantes's guests "like giants immersed in time", so "Tralfamadorians don't see human beings as two-legged creatures, either. They see them as great millepedes - 'with babies' legs at one end and old people's legs at the other" ${ }^{50}$.

In his paper So It Goes, David Velleman ${ }^{51}$ treated Slaughterhouse-Five as an insightful literary reflection on the four-dimensionalist ontology and on what the latter involves for a conception of the self. In this paper, we have shown that In Search of Lost Time can be read in a similar way. On opposite sides of the Atlantic and of the Twentieth century, In Search of Lost Time and Slaughterhouse-Five exploit the power of literature in order to unfold the apparent passage of time into an eternal four-dimensional manifold. In this way, they shed some light on what it means to exist as a momentary part of an atemporal being.

\footnotetext{
${ }^{47}$ Ibidem, our emphasis.

${ }^{48}$ Vonnegut 1969: 20.

${ }^{49}$ Ibidem.

${ }^{50}$ Ibidem: 75.

${ }^{51}$ Velleman 2006.
} 
References

Bergson, $\mathrm{H}$.

- 1896, Matière et mémoire. Essai sur la relation du corps à l'esprit, Paris, Félix Alcan.

BonOMI, A.

- 1987, Le immagini dei nomi, Milano, Garzanti.

BROAD, CH.D.

- 1923, Scientific Thought, New York, Harcourt, Brace and Co.

CAMERON, R.P.

- 2015, The Moving Spotlight: An Essay on Time and Ontology, Oxford, Oxford University Press.

Currie, G.

- 2004, Can there be a literary philosophy of time?, in Id., Arts \& Minds, Oxford, Clarendon: 84-104.

DANCY, J.

- 1995, New truths in Proust?, "The Modern Language Review”, 90, 1: 18-28.

Deleuze, G.

- 1964, Proust et les signes, Paris, Presses Universitaires de France.

DennetT, D.

- 1991, The reality of selves, in Consciousness Explained, Boston, Little, Brown and Company.

Durán, R.

- 1991, Fourth-dimensional time and Proust's "A la recherche du temps perdu", "South Atlantic Review”, 56, 2: 73-90.

Genette, G.

- 1966, Proust palimpseste, in Figures I, Paris, Seuil: 39-67.

Husserl, E.

- 1928, Vorlesungen zur Phänomenologie des inneren Zeitbewusstseins; On the Phenomenology of the Consciousness of Internal Time, transl. by G.B. Brough, Dordrecht, Kluwer Academic Publishers 1991.

JAMES, W.

- 1890, The Principles of Psychology, 2 vols., New York, Henry Holt; repr. as a single volume, Cambridge, Mass, Harvard University Press 1983.

KRIEGEL, U.

- 2015, Experiencing the present, "Analysis", 75, 3: 407-413.

LAGO, E.

- 2005, La volontà di potenza e il passato. Nietzsche e Gentile, Milano, Bompiani.

MACKIE, J.L.

- 1977, Ethics: Inventing Right and Wrong, London, Penguin.

MarTin, M.

- 2002, The transparency of experience, "Mind \& Language", 17, 4: 376-425.

McTagGaRT, J.E.

- 1908, The unreality of time, "Mind", 4, 1: 457-474.

MeLlor, D.H.

- 1998, Real Time II, London, Routledge. 
Merleau-Ponty, M.

- 1945, Phénoménologie de la perception, Paris, Gallimard.

- 1962, Phenomenology of Perception, London - New York, Routledge \& Kegan Paul. Nö̈, A.

- 2006, Experience of the world in time, "Analysis", 66, 289: 26-32.

PAuL, L.A.

- 2013, Temporal experience, in The Future of the Philosophy of Time, New York, Routledge: 109-132.

Proust, M.

- 1913-1927, À la recherche du temps perdu, Paris, Grasset and Gallimard; In Search of Lost Time, transl. by C.K. Scott Moncrieff, Modern Library, New York, 1992.

Quine, W. van OrMaN

- 1987, Quiddities: An Intermittently Philosophical Dictionary, Cambridge (Mass.), Harvard University Press.

Ricceur, P.

- 1984, La Configuration du temps dans le récit de fiction. Paris, Seuil, vol. 2 of Temps et récit, 3 vols, 1983-1985.

Russell, B.

- 1913, On the Experience of Time, in The Collected Papers of Bertrand Russell, vol. 7, London, Allen and Unwin.

Sider, TH.

- 2011, Writing the Book of the World, Oxford, Oxford University Press.

Sкоw, B.

- 2009, Relativity and the moving spotlight, "Journal of Philosophy", 106, 12: 666-678.

SNOWDON, P.

- 1998, Strawson on the concept of perception, in The Philosophy of P. F. Strawson, London, Open Court.

Strawson, G.

- 2009, Selves: An Essay in Revisionary Metaphysics, Oxford, Oxford University Press.

STRAWSON, P.F.

- 1959, Individuals: an essay in descriptive metaphysics, London, Methuen.

- 1966, Self, mind and body, in "Common Factor", 4; reprinted in Id., Freedom and Resentment and Other Essays, London, Methuen: 186-195.

- 1974, Causation in Perception, in Freedom and Resentment and Other Essays, London, Methuen: 73-93.

- 1979, Perception and its Objects, in Perception and Identity: Essays Presented to A.J. Ayer, ed. by G.F. Macdonald, London, MacMillan, 1979: 41-60.

VARZI, A.

- 2001, Parole, oggetti, eventi e altri argomenti di metafisica, Roma, Carocci.

Velleman, J.D.

- 2006, So It Goes, "The Amherst Lecture in Philosophy”, 1: 1-23.

VonNegut, K. JR.

- 1969, Slaughterhouse Five; Or The Children's Crusade, New York, Dell Publishing. 